\title{
KAT6A/CREBBP Fusion Gene
}

National Cancer Institute

\section{Source}

National Cancer Institute. KAT6A/CREBBP Fusion Gene. NCI Thesaurus. Code C99497.

A fusion gene that results from a chromosomal translocation $t(8 ; 16)(p 11 ; p 13)$ which fuses the 5' portion of the KAT6A gene to most of the coding region of the CREBBP gene. This rearrangement is associated with acute myeloid leukemia. 